\title{
Reducing service points in the academic library How to provide quality customer service in the face of budget cuts
}

$\mathbf{M}$ ost academic libraries have been experiencing cutbacks in staff and resources and are expected to do more with less. In response to a statewide financial downturn, the University of North Texas (UNT) Libraries created a strategy to reduce the number of staffed service points. By the end of spring 2012, UNT Libraries had successfully merged six service points into one. This article presents an overview of the steps the Public Services Division took to effectively manage these mergers and cross train library support staff, as well as provide suggestions for other libraries considering streamlining their service points.

\section{From many service points to few}

UNT is an advanced degree granting institution with a population of more than 35,000 students, 1,000 faculty members, and 3,500 staff. The UNT Libraries, the most widely used service on campus, provide access to more than 7 million items in print and digital formats. ${ }^{1}$ In 2009 the Public Services Division staffed six service desks in Willis Library, all located on the first floor of the library:

- check out,

- circulation,

- interlibrary loan,

- fines,

- reserves, and

- reference

The Willis Library check out desk was staffed with student assistants who monitored the alarm gate, checked out books, and provided basic directional information. There was a long desk just past the check out desk that was staffed by circulation staff on one end and by interlibrary loan on the other end, providing two separate services with two separate book drops, but with no discernible difference in the two areas from the patron's perspective. Our fines desk in Willis Library was located near circulation but behind a separate door. We had a reference desk hiding in one corner of the first floor, and a reserves desk hiding in the other. Since both started with the letter "R," there was a 50/50 chance a patron would end up at the wrong desk when referred. Public services staff spent a good portion of their day playing "pass the patron," referring from one desk to another, and on several occasions patrons got frustrated by not being able to take care of their library business in one location, or were embarrassed because they did not know where they should go to receive the services they needed.

In summer 2010, the assistant dean of public services began investigating ways to improve our public image and bring the departments together in a cohesive and meaningful way that would not only benefit the patrons but also the staff. A major restructure was the creation of the Access Services department, which brought several services into one group.

Another major restructure was a small renovation to the first floor of the library.

Julie Leuzinger is department head at Eagle Commons Library at the University of North Texas, e-mail:jam0112@ unt.edu

๑ 2013 Julie Leuzinger 
The circulation workroom was expanded by removing a wall, moving the reserves collection to the circulation area, and creating a processing area for interlibrary loan in the former reserves area. In one very inexpensive remodel we were able to move four services to one desk (reserves, circulation, interlibrary loan, and fines), which created a one-stop area for our patrons for all Access Services-related library business. We did lose one service point in this restructure, the separate check out desk; however, it was turned over to our facilities and systems division, where students staff the desk 24 hours a day, seven days a week when classes are in session. They monitor the alarm gates and provide basic tech help, as well as check out laptops.

\section{Handling the change}

Change is not easy. For some, it was hard to imagine an academic library with no reference desk, especially when the sole reason many of us went to library school was to be academic reference librarians. But we had six months to warm up to the idea (from November 2011 to June 2012) and to coordinate the merger. An ad hoc committee of three Access Services staff members and three reference staff members were tasked with the coordination of the merger to the single service desk, discussing ways of working out the changes with the staff, and creating and planning cross training.

The committee determined the best time for the move would be over the summer so that we would be able to identify as many staffing or training issues as possible before the rush of the fall semester started, so the launch date was set for June 1, 2012. The first half of the spring 2012 semester was spent discussing the best way to go about training and preparing the staff, researching other libraries that had removed their reference desks, and interviewing other librarians who had undergone similar projects to get an idea of what challenges and pitfalls they encountered.

\section{For some, it was hard to imagine an academic library with no refer- ence desk, especially when the sole reason many of us went to library school was to be academic reference librarians.}

Our assistant dean also wanted the committee to find ways of minimizing librarian time at the desk so they could focus on liaison duties like library instruction, reference by appointment, outreach, and marketing. It was a tall order, but the committee came up with a training plan, as well as steps to move most of the librarians from the desk.

\section{Cross-training the staff}

The committee decided to have Graduate Library Assistants (GLAs)—UNT students working toward their Master's in Library Science-start working two hours per week at the Access Services Desk beginning during spring break 2012. Our GLAs would be well versed in circulations tasks by the time the merger occurred, and we wanted to get library patrons used to seeing reference desk staff at a new desk. Since the GLAs had also been working at the ECL Service Desk, they were already familiar with the types of circulation tasks they would need to perform. Our Access Services support staff shadowed librarians at the reference desk for a few hours per week so they would become familiar with frequently asked reference questions.

The committee arranged three reference training sessions for the access services staff before the June 1 deadline. The first training covered reference interviews and referrals. We discussed the steps of the reference interview and how and when to make a referral to a subject specialist. We also did several interview role playing games. At the end of the training session, we included a catalog training assessment for the staff to complete before the next training session, 
so we would know how basic or advanced to gear the next training.

The second training covered using the catalog and subject guides. We discovered that the Access Services staff was very skilled at using our integrated library system because they used it to check books out to patrons. They did not use the online catalog as much, which made it a challenge to instruct patrons on using our online catalog. We also covered using subject guides to recommend resources for patrons at night or on weekends. Again, we followed this training with an electronic resources training assessment so we would know the experience level of the staff for the next training session.

Finally, we provided training on using electronic resources, focusing on Academic Search Complete, to help patrons get started on their research, and did exercises to identify other subject specific electronic resources using the subject guides. In each training session we emphasized that they are already using many of these basic skills, which seemed to be a confidence booster since some were a little nervous about answering reference questions.

Our librarians needed training as well to provide a new service, Librarian on Call. We ordered a set of walkie talkies, one of which stays at the Willis Library Services Desk with a GLA while a librarian takes the other one back to his or her office.

Most librarians take a four-hour shift on-call, and are paged by the GLA if there is a complex reference question or a line at the desk. The librarians can work on other things in their offices during their on-call shift, but their primary duty is to serve as back up and to be available when paged.

\section{Considerations of importance}

One thing in particular that we try to stress to our graduate assistants is that we want to provide the most seamless service experience we possibly can for our patrons. Generally, your average undergraduate students are not thinking about the staff's education level when they visit the desk; if you can help them find the article they need, check out a book, or help them find out if their professor put their text book on reserve, they are not concerned if you are a peer or a Ph.D. Providing seamless service at a blended service desk does not mean you will know how to do everything well, it means you know and appreciate the skills and expertise of those around you so you can follow through with a smooth referral to the appropriate person.

This type of service desk is not meant to diminish the value of the MLS in any way. The degree certainly still has a place in the academic library, but perhaps we need to think about how to use our knowledge and experience in other ways. College students do not have the same information-seeking behaviors they did 20 years ago, or even ten years ago, we need to use our efforts to meet students where they are.

For example, we have librarians providing on-site library research help in dormitories, in group study areas of academic buildings between classes, and even in a permanent office in the same building as the students and faculty in their subject specialization. The work our support staff, GLAs, and student assistants are doing at our service desks allow us to provide these innovative services to our students and faculty.

\section{Areas of strength and weakness}

In December 2012, we collected feedback from those staffing the desk to determine what was working and what could be improved. We did request monthly feedback from staff, but this was the first time we sat down to put together a formal assessment. We also reviewed our reference statistics database to analyze patron feedback, desk traffic patterns, and needed staffing levels.

From our assessment, we determined the following was working well:

- positioning reference and Access Services staff at the same desk allows us to learn from each other; 
- closeness of staff allows patrons to have their needs responded to quickly;

- positive feedback from patrons regarding the one-stop service desk;

- easy to call for full-time reference or Access Services help;

- team work and camaraderie displayed by staff in both departments; and

- good two-way communication from managers and desk staff.

We determined the following could be improved:

- more privacy needed for reference transactions;

- GLAs would learn more if they could hear librarian responses when called (prior to the merged desk graduate assistants had one shift per week on desk with a librarian);

- reference staff wanted more circulation training;

- circulation staff were not using Librarian on Call service when the GLA was busy;

- librarians on-call should stop by the service desk at the beginning of shift;

- set up and organization of the service desk needs to be planned and revised; and
- overall training methods for both sets of staff need to be reviewed and improved with core competencies for reference and circulation.

We have experienced a boost in staff morale, camaraderie, and trust across the two departments because staff have a greater understanding and appreciation for the skills their co-workers bring to the table. Communication between access services and reference is more frequent and improved. Desk coverage is much easier, due to the numbers of cross-trained staff. Student assistant costs have been reduced. We are now providing a better service for our patrons overall, given their verbal feedback at our service desk as well as through anonymous surveys. Our patrons are appreciative of and responsive to our new service model and our single service point desk.

\section{Note}

1. Office of Institutional Research and Effectiveness, University of North Texas (2012), Fact Book, retrieved from http:// institutionalresearch.unt.edu/sites/default /files/Draft\%231FactBook2011-2012.pdf. $\boldsymbol{n}$

\section{Statement of ownership and management}

College $\&$ Research Libraries News is published 11 times a year (monthly, combining July/August) by the American Library Association, 50 E. Huron St., Chicago, IL 60611. American Library Association, owner; David Free, editor. Second-class postage paid at Chicago, Illinois. Printed in the U.S.A. As a nonprofit organization authorized to mail at special rates (DMM Section 423.12), the purposes, function, and nonprofit status of this organization and the exempt status for federal income tax purposes, have not changed during the preceding 12 months.

Extent and nature of circulation. ("Average" figures denote the number of copies printed each issue during the preceding twelve months; "Actual" figures denote the number of copies of single issues published nearest to filing date.) Total number of copies (net press run): Average, 12,881 Actual, 12,781. Total paid/ requested subscriptions: Average, 12,249; Actual, 12,249.
Sales through dealers and carriers, street vendors, counter sales, and other non-USPS paid distribution: not applicable. Other classes mailed through the USPS: not applicable. Total paid and/or requested circulation: Average, 12,249 Actual, 12,249. Free distribution by mail: Average, 126; Actual, 84. Free distribution outside the mail: Average, 0; Actual, 0. Total free distribution: Average, 126; Actual, 84. Total distribution: Average, 12,375; Actual, 12,333. Copies not distributed: Office use, leftover, spoiled: Average, 506; Actual, 448. Total (sum of previous entries): Average, 12,881 Actual, 12,781. Percent paid and/or requested circulation: Average, 98.9\%; Actual, $99.3 \%$.

Statement of ownership, management, and circulation (PS Form 3526, August 2012) for 2012 filed with the United States Postal Service, Postmaster in Chicago, Illinois, August 28, 2013. 